www.gjsoc.eu

\title{
Perceptions in Nigeria and United States of America relations
}

Umar Ubandawaki *,

Suggested Citation:

Abstract 
1. Introduction

2. Objectives of the Paper

3. Methodology 

4. Contexts of Perception in the Relations 


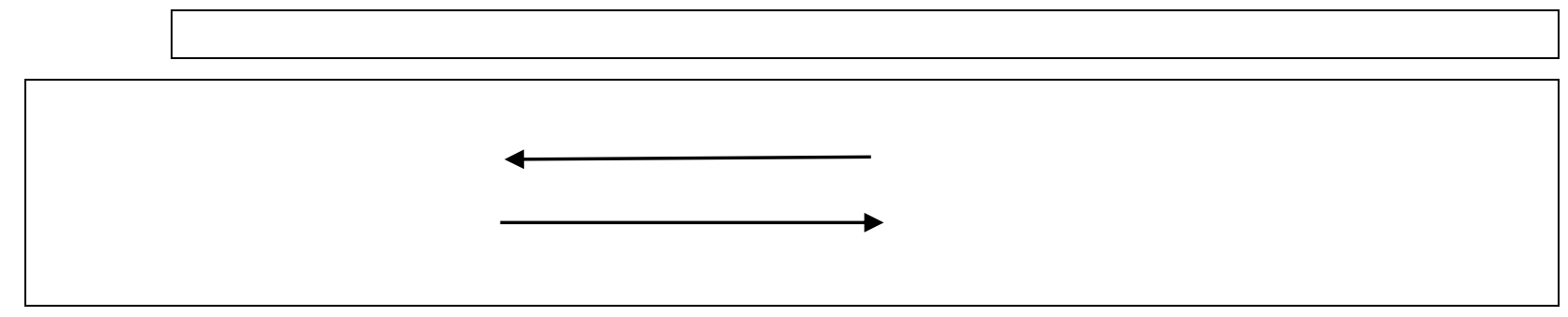




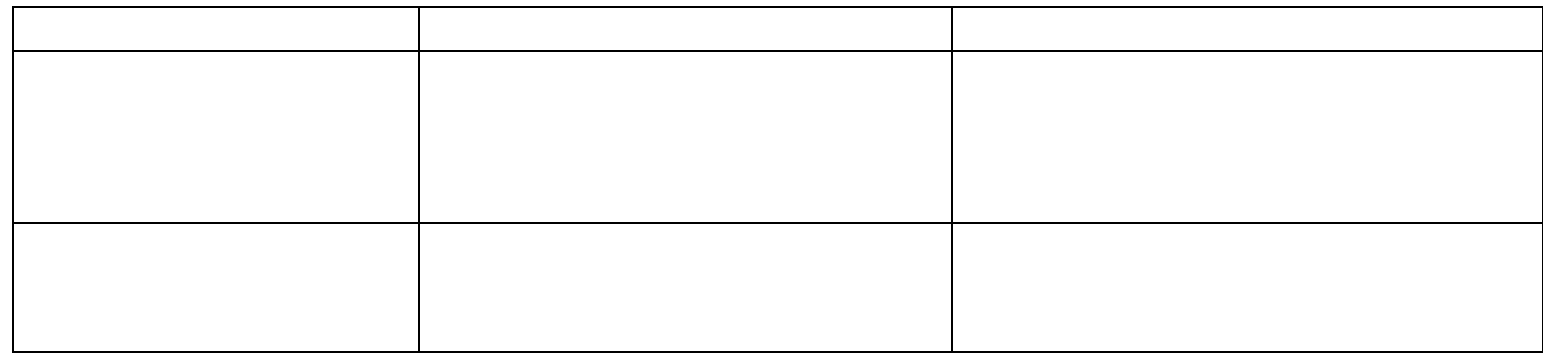

Key

Note 


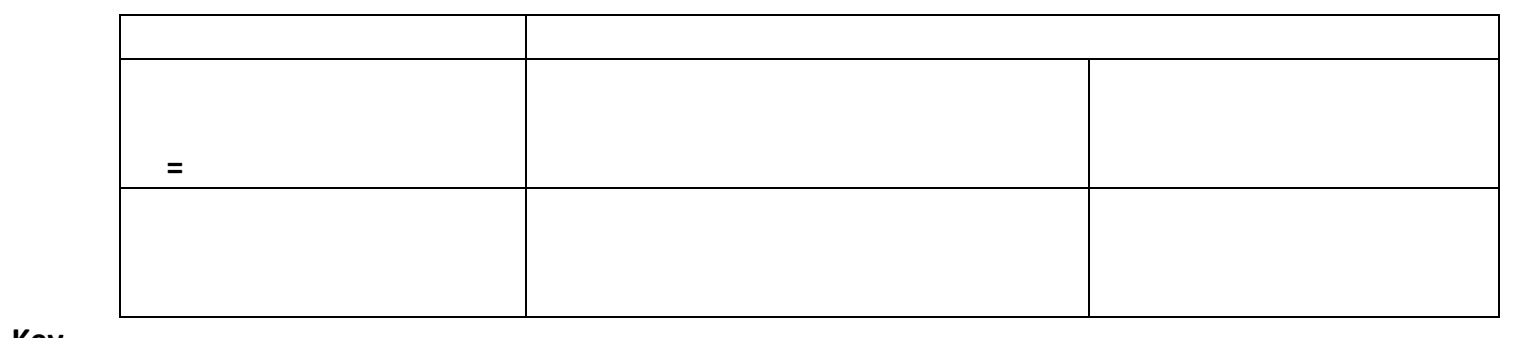

$\underline{\text { Key }}$ 


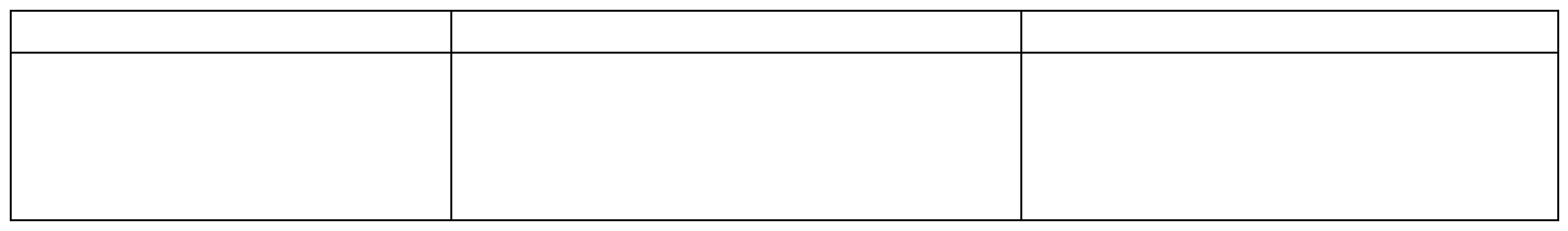




\begin{tabular}{|l|l|l|}
\hline & & \\
\hline & & \\
& & \\
\hline Key & & \\
\hline
\end{tabular}


5. Suggestions for Future Research 
References 